\title{
The Relationship of Learning Interest to Science Online Learning Outcomes for Third-Grade Elementary School
} Students

\author{
Komang Suardi Wiradarma ${ }^{1}$, Ni Ketut Suarni2 ${ }^{2}$, Ndara Tanggu Renda ${ }^{3}$
}

1,2,3 Program Studi Pendidikan Guru Sekolah Dasar, Universitas Pendidikan Ganesha, Singaraja, Indonesia

\section{ART ICLE INFO}

Article history:

Received June 08, 2021

Revised June 11, 2021

Accepted August 01, 2021

Available online August 25, 2021

Kata Kunci:

Minat Belajar, Hasil Belajar

Daring

Keywords:

Interest Learning, Online

Learning Outcome

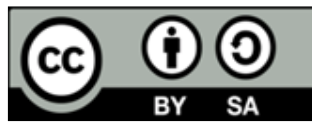

This is an open access article under the CC BY-SA license.

Copyright $(2021$ by Author. Published by Universitas Pendidikan Ganesha.

\begin{abstract}
A B S T R A K
Kesulitan guru dalam menumbuhkan minat belajar siswa dalam pembelajaran daring menyebabkan rendahnya hasil belajar siswa khususnya dalam pembelajaran IPA. Selama adanya pandemi COVID-19 pembelajaran di Indonesia dilakukan secara daring pada setiap jenjang pendidikan termasuk pada jenjang sekolah dasar. Sehingga diperlukan minat belajar siswa yang tinggi untuk mencapai hasil belajar yang maksimal. Penelitian ini bertujuan untuk menganalisis hubungan antara minat belajar terhadap hasil belajar daring IPA. Jenis penelitian yang digunakan penelitian expost facto. Jumlah populasi dan sampel berjumlah 60 siswa. Pengambilan data dengan menggunakan kuesioner. Teknik analisis data menggunakan regresi sederhana dan regresi ganda dengan menggunakan SPSS. Hasil penelitian menunjukkan minat belajar dan hasil belajar saling mempengaruhi. Terjadi korelasi positif yang signifikan antara minat belajar dengan hasil belajar siswa yang memperoleh nilai $F_{\text {hitung }}>F_{\text {tabel }}(0,302>0,254)$. Jadi, terdapat hubungan yang signifikan antara minat belajar terhadap hasil belajar daring IPA siswa kelas III SD secara terpisah dan simultan. Minat belajar siswa yang tinggi maka hasil belajar IPA siswa akan meningkat. Implikasi penelitian ini adalah untuk meningkatkan kinerja guru serta peran aktif orangtua untuk menumbuhkan minat belajar siswa yang akan bermuara terhadap peningkatan hasil belajar siswa.
\end{abstract}

\section{A B S T R A C T}

The difficulty of teachers in fostering student interest in online learning causes low student learning outcomes, especially in science learning. During the COVID-19 pandemic, learning in Indonesia was carried out online at every level of education, including at the elementary school level. So it takes a high student interest in learning to achieve maximum learning outcomes. This study aims to analyze the relationship between learning interest on science online learning outcomes. This type of research is ex post facto research. The number of populations and samples in this study was 60 students. Data collection techniques using a questionnaire. The data analysis used is simple regression and multiple regression using SPSS. The results showed that interest in learning and learning outcomes influenced each other. There was a significant positive correlation between interest in learning and student learning outcomes who scored $F_{\text {count }}>F_{\text {table }}(0.302>0.254)$. So, there is a significant relationship between learning interest and online science learning outcomes for third grade students of Primary School Cluster III separately and simultaneously. The higher the student's interest in learning, the student's science learning outcomes will increase. The implication of this research is to improve teacher performance and the active role of parents to foster student interest in learning which will lead to improving student learning outcomes.

\section{INTRODUCTION}

In science learning, students should be active in learning, and students have the opportunity to acquire and experience the material in learning (Lusidawaty et al., 2020; Prananda et al., 2020; Meo et al., 2021; Mahmud et al., 2018). Planting basic science concepts in science content learning at the elementary school level aims to make students aware of the surrounding environment and solve problems related to 
natural events that often occur. Students' interest in following the learning process requires guidance in learning so that students haton learning. Science learning is expected to be an arena for students to learn about themselves and the natural environment to apply it in everyday life (Pascarella et al., 2020; Roebianto, 2020). Internal factors and external factors influence the achievement of student learning outcomes. Factors that come from within the person who learns (internal) include health, intelligence and talent, interests and motivation, and ways of learning, and some from outside (external) include the family environment, school, community, and the surrounding environment (Awe \& Benge, 2017). One of the factors from within students that affect learning outcomes is interest in learning. Without students' interest in learning to encourage student's enthusiasm for learning, it will affect student learning outcomes (Karina et al., 2017; Riwahyudin, 2015). Therefore, we need learning that can attract students' interest in learning, especially in learning science. So, to improve student learning outcomes, student interest in learning is needed, which determines the achievement of learning objectives.

In elementary schools today, the reality is that students experience a decrease in learning outcomes due to a lack of interest in learning. They tend to be lazy to learn because of a lack of interaction with the school environment, especially science learning. Most children are closely related to technology because technology is considered more colorful than interacting with their surroundings (Fakhruddin et al., 2019; Safitri et al., 2020). The results of PISA (the program for international student assessment) in 2018 showed Indonesia's scientific ability was ranked 71st out of 79 countries with an average score of 389 (Hewi \& Shaleh, 2020). This happens because there are problems in learning science that result in low student learning outcomes. One of the problems in learning science is the low interest in student learning which causes students' low desire to learn (Karina et al., 2017; Ningsih et al., 2018; Wulandari et al., 2017). The existence of the COVID-19 pandemic has caused the implementation of learning in Indonesia to be carried out online (in the network). Coronavirus Diseases 2019 (COVID-19) is a disease with common symptoms of respiratory disorders such as fever, cough, and shortness of breath (Kolta \& Ghonimy, 2020; Dewi, 2020; Handayani et al., 2020). Indonesia is one of the countries affected by the COVID-19 virus, so to stop the spread of this virus, learning is carried out remotely or online (in the network) (Dewi, 2020; Malyana, 2020; Mulyanti et al., 2020). Therefore, to maximize learning, learning tools or media are needed that can attract students' interest during online learning.

Interviews with classroom teachers showed that students' interest in learning was still low during the online learning process. The obstacles experienced by teachers in growing and increasing students' interest in learning are still found in elementary school learning. Increasing student interest in learning requires efforts from teachers to design learning that can foster students' willingness to learn (Awe \& Benge, 2017;Febriliani, 2018;Colasante \& Douglas, 2016). Factors that affect learning outcomes consist of two factors, namely internal and external factors. Internal factors come from within the individual concerned, namely, physical and psychological conditions such as learning styles, learning motivation, concentration, high self-confidence, intelligence, study habits, and others. In comparison, external factors come from outside the individual concerned or his environment, for example, family, facilities and infrastructure, curriculum, and others (Gillani, 2021; Lau et al., 2021; Ricardo \& Meilani, 2017). The internal factor that plays the most role is interest in learning because a high interest in learning can encourage students to be active and motivated to learn to achieve learning outcomes (Rosiana, 2018; Sutarto et al., 2020). Interest in learning has a significant influence on learning outcomes because if there is interest in learning in students, it will make students want to learn (Febriliani, 2018; Rosalina \& Junaidi, 2020). If the reality that occurs in the current online learning process is not immediately addressed, it will impact the low quality of human resources and the quality of science learning in Indonesia in the future.

Internal factors and external factors influence the success of teachers in increasing student interest in learning. Internal factors are factors in students which consist of; health, drives, motives, and emotions (Nabillah \& Abadi, 2019; Novika Auliyana et al., 2018). Health problems can affect students' interest in learning because if students are in good health, students' interest in learning will increase. On the encouragement factor, attitude changes can occur if there is encouragement from himself (Alilateh \& Widyantoro, 2019; LaForce et al., 2017). In the motive factor, circumstances can lead to an urge to do certain activities. On the emotional factor, students who feel successful in something will be proud and foster interest in doing it again. External factors come from outside of students, including learning materials and attitudes of teachers, family, friends, and the environment (Ho \& Ismawan Prasetia Devi, 2020; Neppala et al., 2018). On the factor of learning materials and teacher attitudes, the teacher can foster student interest in learning by paying attention to learning materials (Asrial et al., 2020; Chilmi et al., 2020). On the family factor, support, attention, and family guidance are needed to foster student interest in learning, especially from parents. On the factor of friends, the direction of student interest is strongly influenced by their friends. On environmental factors, the growth and development of student 
interest in learning are strongly influenced by their environment (Karina et al., 2017; Primamukti \& Farozin, 2018). Growing and developing students' interest in learning is very necessary for the role of teachers and parents so that student learning outcomes can increase.

Research conducted shows a relationship between student interest in learning and student learning outcomes (Karina et al., 2017; Budiwibowo, 2016; Wulandari et al., 2017; Ningsih et al., 2018). Other findings also state that interest can impact student learning outcomes (Awe \& Benge, 2017; Febriliani, 2018). The higher the student's interest, the higher the learning outcomes (Toma \& Greca, 2018). The relationship between student interest in learning and online science learning outcomes is significant to study. So, this study aims to analyze the relationship between interest in learning and online learning outcomes in science. Analyzing the relationship between interest in learning and students' online learning outcomes can make teachers and parents pay more attention to students' interest in learning. The collaboration of teachers and parents to foster student interest in learning can improve students' online science learning outcomes.

\section{METHOD}

This type of research is ex post facto research that examines the relationship between students' interest in learning and students' online learning outcomes in science content. The independent variable interests in learning in this study, while the dependent variable is the student's science learning outcomes. Ex-post facto research is an approach without treatment to bring up the variables to be studied in the research subject (Rizqi \& Sumantri, 2019; Juniarti et al., 2020). Ex-post facto research aims to reveal the relationship of two or more variables without manipulation (Sugiartini et al., 2019; Wulandari \& Renda, 2020). This research was conducted in SD Cluster III, Gerokgak District, in class III with 60 students. The population is a set of similar elements. There is a generalization area in the population consisting of objects/subjects that have certain qualities and characteristics determined by the researcher to be studied and then drawn conclusions. So the population is all students to be studied, and the population in this study using a sample. The sample is part of the population taken, considered representative of the population, and taken using specific techniques (Anggraini et al., 2017). Thus the sample is part of the population determined by the researcher to be studied and then drawn conclusions. In this study, the sample was taken using a random sampling technique. From this technique, the number of research samples was determined, namely 60 students.

The data collection method was carried out to find supporting data in a study. The method used in this study includes data on interest in learning and data on learning outcomes. The method used in the collection uses the method of recording documents for learning outcomes and the method of collecting data on parenting and motivation using non-test methods. The non-test method is in the form of a questionnaire/questionnaire. The questionnaire/questionnaire method obtains or collects data by sending a list of questions/statements to respondents/research subjects (Agung, 2014). So the questionnaire can be interpreted as a technique that uses a statement that the respondent will answer to collect information by reality or data related to research. The following is a grid of learning interest questionnaire instruments in Table 1.

Table 1. Grid of Learning Interest Instruments

\begin{tabular}{|c|c|c|c|c|c|}
\hline \multirow{2}{*}{$\begin{array}{l}\text { Indicator } \\
\text { Variables }\end{array}$} & \multirow[t]{2}{*}{ Number } & \multirow{2}{*}{$\begin{array}{c}\text { Question } \\
\text { Points }\end{array}$} & \multicolumn{2}{|c|}{ Question Points } & \multirow{2}{*}{$\begin{array}{l}\text { Number of } \\
\text { Questions }\end{array}$} \\
\hline & & & $(+)$ & $(-)$ & \\
\hline \multirow[t]{4}{*}{ Minat Belajar } & Perasaan senang & $1,4,5,7,9$ & $1,4,5$ & 7,9 & 5 \\
\hline & $\begin{array}{l}\text { Ketertarikan } \\
\text { siswa }\end{array}$ & $2,3,6,8,10$ & $3,8,10$ & 2,6 & 5 \\
\hline & Perhatian siswa & $11,12,14,17,18$ & $11,14,17$ & 12,18 & 5 \\
\hline & Keterlibatan siswa & $13,15,16,19,20$ & $13,19,20$ & 15,16 & 5 \\
\hline \multicolumn{5}{|c|}{ Jumlah } & 20 \\
\hline
\end{tabular}

The data analysis technique used is product moment analysis. When testing the hypothesis, which reads "a significant relationship between learning interest and students' online science learning

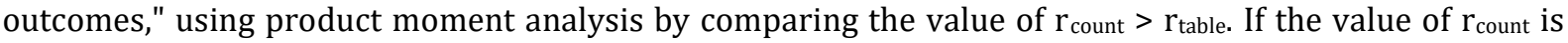

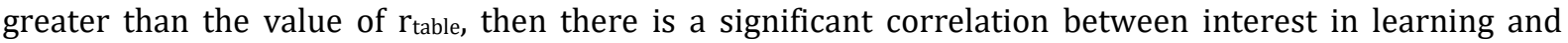
learning outcomes with $\mathrm{H}_{0}$ rejected and $\mathrm{H}_{\mathrm{a}}$ accepted. However, if the value of $\mathrm{r}_{\text {count }}$ is smaller than the value

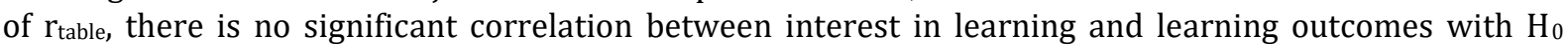
accepted and $\mathrm{H}_{\mathrm{a}}$ rejected. 


\section{RESULT AND DISCUSSION}

Result

Based on the results of data analysis, the frequency distribution can be seen that the highest frequency values are in the 86-90th interval class with a range of 88.5 values as much as $38.3 \%$. The data obtained were analyzed to determine the average (Mean), the mean (Median), and the values that occur frequently (Modus). The results of these calculations obtained an average value (mean) of (87.23). The median value (median) is 88.37. The value that often appears (mode) is 88.8, then to determine the quality of the variable interest in learning, the ideal average (Mi) is 60, and the ideal standard deviation (SDi) is 13. The results of data analysis show that the average of the concept of student interest in learning class III SD Cluster III Gerokgak sub-district amounted to 87.23. Based on these data, it can be concluded that the value of student interest in class III SD Cluster III, Gerokgak District is classified as very good.

The results of the data analysis of science learning outcomes in the form of average learning outcomes scores, standard deviations, minimum scores, maximum scores, and ranges processed with the help of SPSS, which are summarized in Table 2 that the Science Learning Outcomes scores are divided into 6 classes. Respondents who have scored with intervals (72 - 75). A total of 5 respondents who have an interval score (76 - 80) as many as 31 people, respondents who have an interval score (81 - 84) as many as 8 people, respondents who have an interval score (85-88) as many as 9 people, respondents who have a score of interval (89-92) as many as 3 people, respondents who have an interval score $(93-$ 96) are 4 people. So that it can be seen that most of the scores obtained by respondents are in the interval $(76-80)$ as many as 31 people, the above data can be analyzed to determine the mean, median, and mode. The results are the mean of (81.47), the media of (80), and the mode of (80). The results of the classification data indicate that the average learning outcome is 81.47 . Based on these data, it can be concluded that the data is classified as very good.

The analysis prerequisite test is carried out before testing the hypothesis. The data obtained is first tested for normality. The results of the normality test of science learning outcomes data and learning interest obtained the Asymp. Sig (2-tailed) value of $0.153>0.05$ on the variable of interest in learning with learning outcomes means that interest data is usually distributed. Based on calculations using Kolmogorov Smirnov, data was obtained from a normal distribution. After performing the normality test, then the linearity test was carried out. Linearity test is used to determine the relationship between the independent variable and the dependent variable. The linearity test in this study was carried out with the help of SPSS. The decision-making of the linearity test is if the significance value (deviation from linearity) $>0.05$, then there is a linear relationship between the independent and dependent variables. If the significance value is $<0.05$, there is no linear relationship between the independent and dependent variables. In learning interest, there is a linearity result of 0.305 . It can be interpreted that the data has a linear relationship.

After the prerequisite, the test has been carried out, and all prerequisite tests have been met, it is continued with hypothesis testing. The test used is the product-moment analysis test. After testing the significance of the coefficient of the product-moment analysis formula, the results obtained rxy $=0.302$. To test the significance of the correlation coefficient, the value of the product-moment table (r) is used for $n=60$. The rtable value for $n=60$ is 0.254 . Then it can be stated $r_{\text {count }}>r_{\text {table. This states that the value }}$ of $r^{\text {count }}$ is significant with a value of 0.302 , so that $\mathrm{H}_{0}$, which reads that there is no significant correlation between interest in learning and learning outcomes in science class III SD Cluster III, Gerokgak District, Gerokgak Regency, is rejected, and Ha is accepted. This shows that there is a significant positive correlation between interest in learning and student learning outcomes. So it can be interpreted that the higher the student's interest in learning, the student's science learning outcomes will increase. The hypothesis testing results indicate a significant relationship between students' interest in learning and online learning outcomes in science for class III Cluster III students, Gerokgak District. The correlation coefficient value of 0.302 is categorized as significant compared to the value of the product-moment table for $\mathrm{n}=60$, which is 0.254 .

\section{Discussion}

This study stated a significant relationship between learning interest and science learning outcomes for third-grade students of SD Gugus III, Gerokgak District, Buleleng Regency. So it can be interpreted that students' interest in learning is very influential on student learning outcomes because the growth of interest in learning in students will encourage students to take part in learning well. The higher students' interest in learning will improve student learning outcomes. Educators have an essential role in growing student interest in learning in addition to parental participation (Budiwibowo, 2016; Gong et al., 2018; Kavenuke et al., 2020). During online learning, teachers must create exciting and meaningful teaching and learning activities to foster student interest in learning (Chang et al., 2020; Daheri et al., 
2020; Permata \& Bhakti, 2020; Windhiyana, 2020). This can be seen from several indicators. First, feeling happy, good interest in learning reflects interest so that there is a change in learning outcomes by the expectations of students and teachers. Students' feelings of pleasure in participating in the learning process can make students more interested in learning activities (Budiwibowo, 2016; Laksono et al., 2016). Some students gave a happy response during online learning because the learning process was not dull. So that students feel more interested in participating in the learning process. Students who have a high interest in learning will feel happy participating in the learning process (Eugenia et al., 2013; Tsai et al., 2018). In addition, high interest can direct students to participate in learning activities well (Luh et al., 2018; Mayang Ayu Sunami \& Aslam, 2021; Sari et al., 2019).

Second, students' interest in learning can increase if there is cooperation between teachers and parents. The collaboration in question is providing attention and assistance during online learning. The attention of parents and teachers has been well sought so that it can increase student interest in learning. Due to the COVID-19 pandemic, learning is carried out online (Atmojo \& Nugroho, 2020; Baber, 2021; Steven RTerrell, 2014). This results in the role of parents and teachers being very influential on students' interest in learning (Aina \& Tuti, 2020; Pennings et al., 2018). The form of parental attention that parents can give to their children is in the form of providing tutoring, providing supervision during learning at home, facilitating children during online learning to create a calm and comfortable learning atmosphere for children (Sun Kwing Cheung \& Yin, 2021; Ni et al., 2021). This is done because the learning process is carried out at home and not directly at school. Therefore, parental attention is very much needed (Le et al., 2019; Mulyani et al., 2021).

Third, some students experience problems related to learning materials during online learning. However, some students have the initiative to overcome the difficulties experienced. This difficulty can be overcome by asking the teacher or parents who accompany the students during the learning process. This shows a willingness to learn to overcome these problems (Sum Kwing Cheung \& Kwan, 2021; Dong et al., 2020). Interest is the most crucial factor in the learning process. The existence of great interest can affect the way students learn. In addition, learning materials and methods that attract students' interest will be easier to learn and store (Laksono et al., 2016; Pangesti et al., 2017). This is because interest is always associated with attention, feelings of pleasure, and willingness. Student interest in learning is very influential on student learning outcomes because the growth of interest in learning in students will encourage students to take part in learning well (Gan \& Cui, 2020; Steven RTerrell, 2014). The higher students' interest in learning will improve student learning outcomes. Educators have a crucial role in growing student interest in learning in addition to parental participation (Budiwibowo, 2016; Yulianingsih et al., 2020). During online learning, teachers are required to create exciting and meaningful teaching and learning activities in order to foster student interest in learning (Chang et al., 2020; Daheri et al., 2020; Permata \& Bhakti, 2020; Windhiyana, 2020).

The findings of this study are strengthened by previous research, which resulted in a significant relationship between the variables of interest in learning science and learning outcomes in science (Sidiq et al., 2020; Sari et al., 2019). With the high level of interest in learning, the learning outcomes will be high and, conversely, the low interest of students in learning, resulting in low learning outcomes. Other findings also strengthen the results of this study by showing that there is a relationship between student interest in social studies subjects and student learning outcomes (Budiwibowo, 2016). The advantage of this research is that it can produce information about the relationship between interest in learning and student learning outcomes. Through this information, it can be used as material for improvement in learning by paying attention to factors that can foster student interest in learning to improve students' science learning outcomes.

The weakness of this study is that there is no control over interest in learning, so it is more challenging to obtain certainty about the relationship between interest in learning and student learning outcomes. The study results in the form of information regarding the relationship of interest in learning to student learning outcomes can contribute to the world of education in the form of factors that can foster student interest in learning as a step to improve the quality of education in Indonesia. The implications of this research can improve teacher performance and the active role of parents to pay attention and foster student interest in learning so that students can achieve maximum learning outcomes. The limitation of this research is the independent variables that cannot be controlled. This is because the data is taken without manipulating the variables. So it is recommended to add different other variables related to student learning outcomes. 


\section{CONCLUSION}

Students' learning interest has a positive and significant relationship with students' online science learning outcomes. The higher the student's interest in learning, the more students' online science learning outcomes will increase. Factors that influence interest in learning can be used as benchmarks to improve student learning outcomes, especially in online science learning. It is recommended for parents and teachers to continually motivate and accompany children during online learning to improve student learning outcomes, especially science learning.

\section{REFERENCES}

Agung, A. A. G. (2014). Metode Penelitian Pendidikan. Aditya Media Publishing.

Aina, \& Tuti. (2020). Improving Teacher Performance In Classroom Learning Process Through Collaborative Educational Supervisions In Elementary Schools. Primary Jurnal Pendidikan Guru Sekolah Dasar, 9(2). https://doi.org/10.33578/jpfkip.v9i2.7894.

Alilateh, A., \& Widyantoro, A. (2019). The effectiveness of using multiple intelligence activities in listening comprehension and improving students' interest. LingTera, 6(2), 111-118. https://doi.org/10.21831/lt.v6i2.10625.

Anggraini, Hartuti, P., \& Sholihah, A. (2017). Hubungan Pola Asuh Orang Tua Dengan Kepribadian Siswa SMA Di Kota Bengkulu. Consilia: Jurnal Ilmiah Bimbingan Dan Konseling, 1(1), 10-18. https://doi.org/10.33369/consilia.1.1.10-18.

Asrial, Syahrial, Maison, Kurniawan, D. A., \& Piyana, S. O. (2020). Ethnoconstructivism E-Module to Improve Perception, Interest, and Motivation of Students in Class V Elementary School. JPI (Jurnal Pendidikan Indonesia), 9(1), 30-41. https://doi.org/10.23887/jpi-undiksha.v9i1.19222.

Atmojo, A. E. P., \& Nugroho, A. (2020). EFL classes must go online! Teaching activities and challenges during COVID-19 pandemic in Indonesia. Register Journal, 13(1), 49-76. https://doi.org/10.18326/rgt.v13i1.49-76.

Awe, E. Y., \& Benge, K. (2017). Hubungan Antara Minat Dan Motivasi Belajar Dengan Hasil Belajar Ipa Pada Siswa Sd. Journal of Education Technology, 1(4), 231. https://doi.org/10.23887/jet.v1i4.12859.

Baber, H. (2021). Modelling the acceptance of e-learning during the pandemic of COVID-19-A study of South Korea. The International Journal of Management Education, 19(2). https://doi.org/10.1016/j.ijme.2021.100503.

Budiwibowo, S. (2016). Hubungan Minat Belajar Siswa Dengan Hasil Belajar Ips Di Smp Negeri 14 Kota Madiun. Gulawentah:Jurnal Studi Sosial, 1(1), 60. https://doi.org/10.25273/gulawentah.v1i1.66.

Chang, T. Y., Hong, G., Paganelli, C., Phantumvanit, P., Chang, W. J., Shieh, Y. S., \& Hsu, M. L. (2020). Innovation of dental education during COVID-19 pandemic. Journal of Dental Sciences, 155. https://doi.org/10.1016/j.jds.2020.07.011.

Cheung, Sum Kwing, \& Kwan, J. L. Y. (2021). Parents' perceived goals for early mathematics learning and their relations with children's motivation to learn mathematics. Early Childhood Research Quarterly, 56. https://doi.org/10.1016/j.ecresq.2021.03.003.

Cheung, Sun Kwing, \& Yin, J. L. (2021). Parents' Perceived Goals for Early Mathematics Learning and Their Relations With Children's Motivation to Learn Mathematics. Early Childhood Research Quarterly, 56(3), 90-102. https://doi.org/10.1016/j.ecresq.2021.03.003.

Chilmi, F. I., Sina, I., \& Utami, W. B. (2020). The Effectiveness of Course Review Horay Learning Model with Adobe Flash Assistance to See Interests Aad Abilities. Mathematics Education Journal, 3(2). https://doi.org/10.22219/mej.v3i2.11050.

Colasante, M., \& Douglas, K. (2016). Prepare-participate-connect: Active learning with video annotation. Australasian Journal of Educational Technology, 32(4), 68-91. https://doi.org/10.14742/ajet.2123.

Daheri, M., Juliana, J., Deriwanto, D., \& Amda, A. D. (2020). Efektifitas WhatsApp sebagai Media Belajar Daring. Jurnal Basicedu, 4(4), 775-783. https://doi.org/10.31004/basicedu.v4i4.445.

Dewi, W. A. F. (2020). Dampak COVID-19 terhadap Implementasi Pembelajaran Daring di Sekolah Dasar. Jurnal Edukatif Ilmu Pendidikan, 2(1). https://doi.org/10.31004/edukatif.v2i1.89.

Dong, C., Cao, S., \& Li, H. (2020). Young Children's Online Learning during COVID-19 Pandemic: Chinese Parents' Beliefs and Attitudes. Child Youth Serv Rev, 118. https://doi.org/10.1016/j.childyouth.2020.105440.

Eugenia, Raymond, \& Leung, W. N. (2013). Ready for 21st-century Education - Pre-service Music Teachers Embracing ICT to Foster Student-centered Learning. Procedia - Social and Behavioral Sciences, 73. https://doi.org/10.1016/j.sbspro.2013.02.047.

Fakhruddin, Z., Amzah, A., \& Nurchalis, N. F. (2019). Technology-Based Teaching Material Development 
Training for Pre-Service Teachers to Improve Students' Learning Outcomes. NOBEL: Journal of Literature and Language Teaching, 10(1), 87-102. https://doi.org/10.15642/nobel.2019.10.1.87102.

Febriliani, L. (2018). Hubungan Minat Belajar Dan Fasilitas Belajar Terhadap Hasil Belajar Matematika Kelas V. Joyful Learning Journal, 7(2), 10-18. https://doi.org/10.15294/jlj.v7i2.24049.

Gan, M., \& Cui, H. (2020). Exploring user movie interest space: A deep learning based dynamic recommendation model. Expert Systems with Applications, 173. https: //doi.org/10.1016/j.eswa.2021.114695.

Gillani, A. A. (2021). The association between presence of sanitation facilities and school enrolment in Pakistan. World Development Perspectives, 21. https://doi.org/10.1016/j.wdp.2021.100289.

Gong, Y., Hu, X., \& Lai, C. (2018). Chinese as a second language teachers' cognition in teaching intercultural communicative competence. System, 78. https://doi.org/10.1016/j.system.2018.09.009.

Handayani, D., Hadi, D. R., Isbaniah, F., Burhan, E., \& Agustin, H. (2020). Corona virus disease 2019. Jurnal Respirologi Indonesia, 40(2), 119-129. https://doi.org/10.36497/jri.v40i2.101.

Hewi, L., \& Shaleh, M. (2020). Refleksi Hasil PISA (The Programme For International Student Assesment): Upaya Perbaikan Bertumpu Pada Pendidikan Anak Usia Dini). Jurnal Golden Age, 4(1). https://ejournal.hamzanwadi.ac.id/index.php/jga/article/view/2018.

Ho, L., \& Ismawan Prasetia Devi. (2020). A New trend in understanding students' interest in learning science: microetnography. Integrated Science Education Journal (ISEJ), 1(2), 62-66. https://doi.org/10.37251/isej.v1i2.72.

Juniarti, N. K. R., Margunayasa, I. G., \& Kusmariyatni, N. (2020). Hubungan Antara Pola Asuh Orang Tua dan Konsep Diri dengan Kompetensi Pengetahuan Matematika Siswa. Jurnal Ilmiah Sekolah Dasar, 4(1), 17. https://doi.org/10.23887/jisd.v4i1.24273.

Karina, R. M., Syafrina, A., \& Habibah, S. (2017). Hubungan Antara Minat Belajar Dengan Hasil Belajar Siswa Dalam Mata Pelajaran Ipa Pada Kelas V Sd Negeri Garot Geuceu Aceh Besar. Jurnal Ilmiah Pendidikan Guru Sekolah 61-77. http://www.jim.unsyiah.ac.id/pgsd/article/view/4396.

Kavenuke, P. S., Kinyota, M., \& Kayombo, J. J. (2020). The critical thinking skills of prospective teachers: Investigating their systematicity, self-confidence and scepticism. Thinking Skills and Creativity, 37, 100677. https://doi.org/10.1016/j.tsc.2020.100677.

Kolta, M. F., \& Ghonimy, M. B. I. (2020). COVID-19 variant radiological findings with high lightening other coronavirus family (SARS and MERS) findings: radiological impact and findings spectrum of corona virus (COVID-19) with comparison to SARS and MERS. Egyptian Journal of Radiology and Nuclear Medicine, 51(1). https://doi.org/10.1186/s43055-020-00262-7.

LaForce, M., Noble, E., \& Blackwell, C. (2017). Problem-Based Learning (PBL) and Student Interest in STEM Careers: The Roles of Motivation and Ability Beliefs. Education Sciences, 7(4), 92. https://doi.org/10.3390/educsci7040092.

Laksono, Y. S., Ariyanti, G., \& Santoso, F. G. I. (2016). Hubungan Minat Belajar Siswa Terhadap Prestasi Belajar Matematika Siswa Dalam Pembelajaran Kooperatif Tipe Stad Menggunakan Komik. Jurnal Edukasi Matematika Dan Sains, 1(2), 60-64. https://doi.org/10.25273/jems.v1i2.143.

Lau, E., Hou, H. (Cynthia), Lai, J. H. K., Edwards, D., \& Chileshe, N. (2021). User-centric analytic approach to evaluate the performance of sports facilities: A study of swimming pools. Journal of Building Engineering, 44. https://doi.org/10.1016/j.jobe.2021.102951.

Le, T. T. H., Tran, T., Trinh, T. P. T., Nguyen, C. T., Nguyen, T. P. T., Vuong, T. T., Vu, T. H., Bui, D. Q., Vuong, H. M., Hoang, P. H., Nguyen, M. H., Ho, M. T., \& Vuong, Q. H. (2019). Reading habits, socioeconomic conditions, occupational aspiration and academic achievement in Vietnamese junior high school students. Sustainability (Switzerland), 11(18), 1-29. https://doi.org/10.3390/su11185113.

Luh, N., Retno, P., Darsana, I. W., \& Abadi, I. B. G. S. (2018). Korelasi Antara Minat Belajar dengan Hasil Belajar IPS. Mimbar PGSD Undiksha, 6(3), 202-209. https://doi.org/10.23887/jjpgsd.v6i3.21097.

Lusidawaty, V., Fitria, Y., Miaz, Y., \& Zikri, A. (2020). Pembelajaran Ipa Dengan Strategi Pembelajaran Inkuiri Untuk Meningkatkan Keterampilan Proses Sains Dan Motivasi Belajar Siswa Di Sekolah Dasar. Jurnal Basicedu, 4(1), 168-174. https://doi.org/10.31004/basicedu.v4i1.333.

Mahmud, S. N. D., Nasri, N. M., Samsudin, M. A., \& Halim, L. (2018). Science teacher education in Malaysia: challenges and way forward Siti. Asia-Pacific Science Education ORIGINAL, 4(8), 153-155. https://doi.org/10.1186/s41029-018-0026-3.

Malyana, A. (2020). Pelaksanaan Pembelajaran Daring Dan Luring Dengan Metode Bimbingan Berkelanjutan Pada Guru Sekolah Dasar Di Teluk Betung Utara Bandar Lampung. Pedagogia: Jurnal Ilmiah Pendidikan Dasar Indonesia, 2(1), 67-76. https: //doi.org/10.52217/pedagogia.v2i1.640. 
Mayang Ayu Sunami, \& Aslam. (2021). Pengaruh Penggunaan Media Pembelajaran Video Animasi Berbasis Zoom Meeting terhadap Minat dan Hasil Belajar IPA Siswa Sekolah Dasar. Jurnal Basicedu, 5(4), 19. https://doi.org/10.31004/basicedu.v5i4.1129.

Meo, L., We'u, G., \& BS, Y. N. (2021). Penerapan Model Pembelajaran Inkuiri Dalam Meningkatkan Hasil Belajar IPA Pada Siswa Sekolah Dasar. Jurnal Ilmiah Pendidikan Citra Bakti, 8(1), 38-52. https: //doi.org/10.38048/jipcb.v8i1.97.

Mulyani, E. R., Masrul, \& Astuti. (2021). Analisis Perhatian Orang Tua terhadap Minat Belajar Siswa Kelas IV Sekolah Dasar pada Masa Pandemi Covid 19. Jurnal Pendidikan Tambusai, 5(2), 261-266. https://jptam.org/index.php/jptam/article/view/942.

Mulyanti, B., Purnama, W., \& Pawinanto, R. E. (2020). Distance learning in vocational high schools during the covid-19 pandemic in West Java province, Indonesia. Indonesian Journal of Science and Technology, 5(2). https://doi.org/10.17509/ijost.v5i2.24640.

Nabillah, T., \& Abadi, P. A. (2019). Faktor Penyebab Rendahnya Hasil Belajar Siswa. Sesiomadika, 2(3), 659-663. https://journal.unsika.ac.id/index.php/sesiomadika/article/view/2685.

Neppala, P., Sherer, M. V., Larson, G., Bryant, A. K., Panjwani, N., Murphy, J. D., \& Gillespie, E. F. (2018). An interactive contouring module improves engagement and interest in radiation oncology among preclinical medical students: Results of a randomized trial. Practical Radiation Oncology, 8(4). https://doi.org/10.1016/j.prro.2018.01.001.

Ni, S., Lu, S., Lu, K., \& Tan, H. (2021). The effects of parental involvement in parent-child reading for migrant and urban families: A comparative mixed-methods study. Children and Youth Services Review, 123. https://doi.org/10.1016/j.childyouth.2021.105941.

Novika Auliyana, S., Akbar, S., \& Yuniastuti. (2018). Penerapan Pembelajaran Tematik Terpadu di Sekolah Dasar. Jurnal Pendidikan: Teori, Penelitian, Dan Pengembangan, 3(12), 1572-1582. https://doi.org/10.17977/jptpp.v3i12.11796.

Pangesti, K. I., Yulianti, D., \& Sugianto. (2017). Bahan Ajar Berbasis STEM (Science, Technology, Engineering, and Mathematics) untuk Meningkatkan Penguasaan Konsep Siswa SMA. Unnes Physics Education Journal, 6(3), 54-58. https://doi.org/10.15294/upej.v6i3.19270.

Pascarella, G., Strumia, A., Piliego, C., Bruno, F., Del Buono, R., Costa, F., Scarlata, S., \& Agrò, F. E. (2020). COVID-19 diagnosis and management: a comprehensive review. In Journal of Internal Medicine. https://doi.org/10.1111/joim.13091.

Pennings, H. J. M., Brekelmans, M., Sadler, P., Claessens, L. C. A., van der Want, A. C., \& van Tartwijk, J. (2018). Interpersonal adaptation in teacher-student interaction. Learning and Instruction, 55, 4157. https://doi.org/10.1016/j.learninstruc.2017.09.005.

Permata, A., \& Bhakti, Y. B. (2020). Keefektifan Virtual Class dengan Google Classroom dalam Pembelajaran Fisika Dimasa Pandemi Covid-19. JIPFRI (Jurnal Inovasi Pendidikan Fisika Dan Riset Ilmiah), 4(1), 27-33. https://doi.org/10.30599/jipfri.v4i1.669.

Prananda, G., Saputra, R., \& Ricky, Z. (2020). Meningkatkan Hasil Belajar Menggunakan Media Lagu Anak Dalam Pembelajaran IPA Sekolah Dasar. JURNAL IKA, 8(2), 304-314. https://doi.org/10.36841/pgsdunars.v8i2.830.

Primamukti, A. D., \& Farozin, M. (2018). Utilization of interactive multimedia to improve learning interest and learning achievement of child. Jurnal Prima Edukasia, 6(2), 111-117. https://doi.org/10.21831/jpe.v6i2.19183.

Ricardo, \& Meilani, R. I. (2017). Impak Minat dan Motivasi Belajar Terhadap Hasil Belajar Siswa. Jurnal Pendidikan Manajemen Perkantoran, 2(2), 79. https://doi.org/10.17509/jpm.v2i2.8108.

Riwahyudin, A. (2015). Pengaruh Sikap Siswa Dan Minat Belajar Siswa Terhadap Hasil Belajar Ipa Siswa Kelas V Sekolah Dasar Di Kabupaten Lamandau. Jurnal Pendidikan Dasar, 6(1), 11. https://doi.org/10.21009/jpd.061.02.

Rizqi, A. T., \& Sumantri, M. (2019). Hubungan Antara Motivasi Belajar Dan Pola Asuh Orang Tua Terhadap Hasil Belajar Ipa. Jurnal Imiah Pendidikan Dan Pembelajaran, 3(2), 145-154. https: //doi.org/10.23887/jipp.v3i2.18071.

Roebianto, A. (2020). The Effects of Student's Attitudes and Self-Efficacy on Science Achievement Jurnal Pengukuran Psikologi dan Pendidikan Indonesia. Jurnal Pengukuran Psikologi Dan Pendidikan Indonesia, 9(1), 1-10. https://doi.org/10.15408/jp3i.v9i1.14490.

Rosalina, L., \& Junaidi, J. (2020). Hubungan Minat Belajar Dengan Hasil Belajar Pada Pembelajaran Sosiologi Pada Kelas XII IPS di SMAN 5 Padang. Jurnal Sikola: Jurnal Kajian Pendidikan Dan Pembelajaran, 1(3), 175-181. https://doi.org/10.24036/sikola.v1i3.24.

Rosiana, L. D. (2018). Hubungan Motivasi Belajar dan Sumber Belajar dengan Hasil Belajar IPA Kelas V. Joyful Learning Journal, 7(2), 19-26. https://doi.org/10.15294/jlj.v7i2.24432.

Safitri, Y. A., Baedowi, S., \& Setianingsih, E. S. (2020). Pola Asuh Orang Tua di Era Digital Berpengaruh 
Dalam Membentuk Karakter Kedisiplinan Belajar Siswa Kelas IV. MIMBAR PGSD Undiksha, 8(3), 508-514. https://doi.org/10.23887/jjpgsd.v8i3.28554.

Sari, F. K., Rakimahwati, R., \& Fitria, Y. (2019). Hubungan Minat dengan Hasil Belajar Peserta Didik Pada Pelajaran Matematika Kelas VI SDN 25 Jati Tanah Tinggi. Journal of Elementary Education, 3(2). https://doi.org/10.31004/basicedu.v3i2.18.

Sidiq, D. A. N., Fakhriyah, F., \& Masfuah, S. (2020). Hubungan Minat Belajar Ipa Siswa Kelas V Sd Negeri 2 Pelemkerep Terhadap Hasil Belajar Selamapembelajaran Daring. Progres Pendidikan, 1(3), 243250. https://doi.org/10.29303/prospek.v1i3.31.

Steven RTerrell. (2014). Introduction to the special section of the Internet in Higher Education: The American Educational Research Association's Online Teaching and Learning Special Interest Group. The Internet and Higher Education, 21, 59. https://doi.org/10.1016/j.iheduc.2014.01.001.

Sugiartini, N. K., Pudjawan, K., \& Renda, N. T. (2019). Hubungan Pola Asuh Orang Tua dan Rasa Percaya Diri Terhadap Hasil Belajar IPA Kelas V. Mimbar PGSD, 5(2), 171. https: //doi.org/10.23887/ika.v17i2.19853.

Sutarto, S., Sari, D. P., \& Fathurrochman, I. (2020). Teacher Strategies in Online Learning to Increase Students ' Interest in Learning During COVID-19 Pandemic. Jurnal Konseling Dan Pendidikan, 8(3), 129-137. https://doi.org/10.29210/147800.

Toma, R. B., \& Greca, I. M. (2018). The effect of integrative STEM instruction on elementary students' attitudes toward science. Eurasia Journal of Mathematics, Science and Technology Education, 14(4), 1383-1395. https://doi.org/10.29333/ejmste/83676.

Tsai, Y., Lin, C., Hong, J., \& Tai, K. (2018). The effects of metacognition on online learning interest and continuance to learn with MOOCs. Computers \& Education, 121. https://doi.org/10.1016/j.compedu.2018.02.011.

Windhiyana, E. (2020). Dampak Covid-19 Terhadap Kegiatan Pembelajaran Online Di Perguruan Tinggi Kristen Di Indonesia. Perspektif Ilmu Pendidikan, 34(1), 1-8. https://doi.org/10.21009/pip.341.1.

Wulandari, A. P., \& Renda, N. T. (2020). Hubungan Antara Pola Asuh Orang Tua dengan Motivasi Belajar Matematika Siswa. Mimbar Ilmu, 25(2), 90. https://doi.org/10.23887/mi.v25i2.26068.

Wulandari, S., Marhadi, H., \& Antosa, Z. (2017). Hubungan Minat Belajar dengan Hasil Belajar IPS Siswa Kelas IV SD Negeri Gugus III Kecamatan Rumbai Kota Pekanbaru. Joyful Learning Journal, 6(3), 111. https://doi.org/10.15294/jlj.v6i3.15207.

Yulianingsih, W., Suhanadji, S., Nugroho, R., \& Mustakim, M. (2020). Keterlibatan Orangtua dalam Pendampingan Belajar Anak selama Masa Pandemi Covid-19. Jurnal Obsesi : Jurnal Pendidikan Anak Usia Dini, 5(2), 1138-1150. https://doi.org/10.31004/obsesi.v5i2.740. 